\title{
The Integration of Strategic Management and Intrapreneurship: Strategic Intrapreneurship from Theory to Practice $^{1}$
}

\section{Bulent Guven ${ }^{\text {a }}$}

\begin{abstract}
The concept of strategic intrapreneurship emerges through the combination of two potentials, namely intrapreneurship and strategic management. Strategic intrapreneurship help organizations seek to achieve strategic goals in order to discover innovations and take advantage of today's competitive advantages in the direction of its goals and objectives. Strategic intrapreneurs engage in strategic intrapreneurship in line with their core competencies to provide a sustainable competitive advantage for the enterprise. The main purpose of the study will be to present an approach to the strategic intrapreneurship model that emerges from the combination of entrepreneurship, strategic management and try to explain these concepts in a different approach with both qualitative and quantitative research methods. The quantitative study conducted in terms of strategic intrapreneurship, it is believed that the intrapreneurship and its dimensions show the behaviors of the intrapreneurship and dimensions of the workers are at a high level. The findings from SWOT analysis, which is qualitative research, show that the participants have high level of strategic intrapreneurship behaviors.
\end{abstract}

\author{
Keywords: Strategic \\ Intrapreneurship, \\ Intrapreneurship, Strategy, \\ Strategic Management
}

JEL: M10, M14, M19, L26

Received : 13 September 2019 Revised : 04 November 2019 Accepted : 06 December 2019 Type : Research

\section{Introduction}

Organizations are set up in order to operate for a specific purpose. Every activity carried out in the course of time gives direction to the future of the organization. Developments in economic and communication technologies cause changes in the understanding of classical management systems. It is increasingly difficult to meet the newly emerged needs through the classical management concepts. Changes in social, economic, cultural and political environments in today's world also necessitate change in management systems. Today's current global market and economic demands cause profound and major innovations in organizations and sectors all around the world.

Many businesses are restructuring their activities in radical and meaningful ways in response to these rapid, radical and vital changes against these external and internal forces. The survival of today's companies in this intense global competitive environment is closely related to constant demand for new opportunities and possibilities and force a new understanding of these concepts and essential skills. Changes in environmental factors are fast as businesses are growing and selling their products on international markets while the diversification of customer demands has increased the importance of strategic intrapreneurship. These transformations also strive to take measures against threats while trying to exploit opportunities in 
the environment for strategic intrapreneurs. An idea to be explored in an organization with strategic intrapreneurship provides the most effective use of an opportunity that is meant to be determined through this study.

Strategic intrapreneurship responds to the needs by proactively shaping the future direction of organizations. These developments primarily require organizations to carefully observe their goals and to reformulate and implement strategies that achieve these goals successfully. While companies are working on strategies, they need to pay attention to strategic intrapreneurs which will help both organizations' goals and objectives to meet new products and markets. Enterprises with a system of strategic intrapreneurship will be prepared for changes in the economy. If strategic internal intrapreneurship in the organization is effectively used, the enterprise will be able to utilize its resources efficiently and as a result, the business will grow in a balanced manner and will continue its effectiveness in a competitive environment.

Despite the fact that the strategic intrapreneurship is a new subject, its importance is increasing. The major reasons for this concept's growing significance are: the increasing number of competitors and international competition, the benefits of new and strategic product and service production methods, the inability to use effective and correct time and place of skilled workers, the risk of losing skilled employees.

There are several researches on strategic management and intrapreneurship. However, no serious research on strategic intrapreneurship has been conducted. The purpose of this study is to provide a better understanding of the topic by using a mixed research methodology of qualitative and quantitative research methods. Both methods are used in order to present a new definition on strategic intrapreneurship in organizations. Literature search and field research techniques were taken as basis in the study. First of all, strategic management and introductory issues will be addressed in their respective fields. Literature review will be conducted in the field of strategic intrapreneurship which is a fusion of both themes and will later be applied to the research section. As already mentioned, this work is a combination of qualitative and quantitative research. In research section, in terms of strategic management, the opportunities, threats, strengths and weaknesses of the organizations were identified through qualitative research. Strategic focus points and areas that the organization applies and continues to apply are identified. Then empirical research was carried out on the intrapreneurship of the business. Qualitative research findings were blended in explaining the dimensions of intrapreneurship so that the concept of strategic intrapreneurship can be better understood.

\section{Theoretical Framework and Related Literature}

\subsection{Strategic Management}

The strategy is a planned process in order to reach the determined goals in line with the capabilities of the organization by analyzing the internal situation and the external environment of the organization while taking into account the activities of the competitors. According to Eren (1990: 64); the strategy is the compilation of all the rules and policies that would provide the least possible damage and maximum benefit from the variability within the areas of the organization's activities. According to Ülgen and Mirze (2004: 33); the strategy is result - oriented compilation of long-term and dynamic decisions in order to sustain the life of the business, to create sustainable competitive advantage and to earn a return on the average while taking into account the activities of the competitors.

The strategy in business management includes the decisions and methods taken to achieve the most accurate result in the financial sense, which clarifies the confusion between the functions of the institutions and regulates the characteristics that determine the general objectives. These decisions determine the methods in which the organizations will follow in the course of its development. Organizational strategy is a process involving the whole actions and decisions that determine long-term performance in an organization's management (Koteen, 1997: 21).

Strategic management requires specific planning, budgeting, implementation, control, and supervision mechanisms. Strategic Management is a management technique that enables determination of 
goals and targets for the future in all organizations operating in the public, private or non-profit sectors and the activities to be performed in order to reach these targets (Aktan, 1999: 6). According to Thompson and Strickland (1987: 18-19); strategic management is the process by which managers can form a long-range course, set performance goals, develop strategies to achieve these goals in all relevant domestic circumstances, and implement selected action plans. According to Ertuna (2008); strategic management is to define a mission that will lead to identifying goals and objectives in a realistic and clear way, to determine the direction of an enterprise, to follow and to identify the methods to be followed. Bryson (1988: 5) defines strategic management as an administrative technique that reveals what an organization is doing, the reasons for its existence and the goals it wants to achieve in the future. Strategic management is a broader term than the strategy, and is a process involving top management's environmental analysis with a prioritized strategy for business activities (Parnell, 2014: 28-29). Strategic management is the totality of decisions and activities to develop and implement effective strategies and to control those strategies by evaluating the outcomes of those strategies (Dinçer, 2007).

Strategic management requires decisions to be made based on the strengths and weaknesses of the organization and the sources regarded to be in possession. Along with these factors, decisions facilitate the systematic prediction of long - term changes in the future that will enable the organization to work in an open management of knowledge - based dynamics and development. It is unlikely that strategic management practices that are not considered as a continuous process within the context of a dynamic business world, where environmental factors, production, information and communication technologies have developed and changed in incredible dimensions; commercial boundaries and limitations have been abolished; changes and uncertainties are inevitable (Ülgen \& Mirze, 2004: 31). According to Barca (2009: 35), the development of strategic management thought consists of three major periods:

1. Strategic Planning Understanding Period (1960-1980),

2. Competition strategy understanding period (1980-1990),

3. Understanding of strategy based on basic competencies period (1990 to present).

Strategic approach based on core competencies argues that the point of departure in developing strategy should be business-specific resources and capabilities rather than the sectoral forces proposed by the understanding of competition strategies. Strategic thinking based on core competencies does not refuse the impact of external environmental forces on the strategic success of an organization, but it also includes the main determinants such as human, financial, technological, etc., which are developed within the enterprise and therefore more operational; this is the main competence in the integration of resources (Barca, 2009: 47).

Stages of strategic management process can be listed as strategic consciousness, selection and assignment of strategists, strategic analysis, strategic orientation, strategy formation, application of strategy and strategic control (Ülgen \& Mirze, 2004: 57). In the strategic management processes, the existing resources are sought for ways to increase the efficiency and quality of the services to be provided with the provision of service requests, changes taking place in the demand and the priorities of the services provided (Torlak \& Uzkurt, 1999: 249). The strategic management process is expressed as a whole of information gathering, analysis, selection, decision and implementation actions in order to protect the entity's long-term existence and to ensure sustainable competitive advantage (Ülgen \& Mirze, 2004: 31). With this process, the success and growth of the strategic management and organization are planned and controlled without delay and influence of external factors (Barutçugil, 2004: 53-54).

\subsection{Intrapreneurship}

Contemporary world of competition has emphasized the necessity of ensuring the mobilization of intrapreneurship and the organizational intrapreneurship by noting that the sole action of intrapreneurs who act with the strong emotions of working, achieving and creating is not enough. In general, intrapreneurship 
is defined as the presence of individuals in the workplace, who work within the organization in activities that result in production, service and process innovation.

At the core of intrapreneurship is the spread of intrapreneurial thinking into the organization. Pinchot (1985: 18), who has put great work in the emergence of the intrapreneurship, defines the term as the work of any imaginative person or persons, and emphasizes that these people assume responsibility for creating innovation. Intraprenuership is the process of creating new business, new products and new processes within an organisation by improving organisational profitability and value giving the organization a competitive advantage (Carrier, 1996: 6). Intraprenuership is the process creating a new organisation or innovation within an organisation by an individual or a group of individuals associated with an existing organisation (Sharma \& Chrisman, 1999: 11).

Schumpeter (1934: 88-89) defines entrepreneur: "Although entrepreneurs may be inventors..., they are inventors not by nature of their function...". On the other hand, Intrapreneurs are those who have an intrapreneurial spirit within the organization, who see and capture the opportunity to innovate, but who can turn these ideas and models into real activities that increase the profitability and competitive power of the business they are in, not just bringing in innovation (Kirby, 2003: 300). Luchsinger and Bagby (1987: 11), underlined the most important elements of the intrapreneurs as competitiveness and being ambitious, always questioning status quo, frustrated by bureaucratic systems, focusing on results not activity, motivated by problem-solving, change and innovation.

Intrapreneurship is a type of entrepreneurship that has grown into a new concept and has proven itself in an organizational network or in an established business, and has begun to develop and communicate with other people, it knits and evaluates them with their own talents and values (Top, 2006: 9). Intrapreneurship is the process during which opportunities are monitored and the business takes risks voluntarily (ibrahimoğlu \& Yaşar Uğurlu, 2013: 105). Intrapreneurship aims to mobilize and revitalize the existing organization through risk taking, innovation, competitive behavior and sales (Zahra \& Covin, 1995: 44). In general, internal intrapreneurship, which reveals the sum of intrapreneurship and innovation activities within an organization, is that individuals within an already working organization are directed to act as intrapreneurs (Koçel, 1998: 17).

Internal intrapreneurship, which means entrepreneurship within the organizations is regarded as an important factor in organizational and economic development (Parker, 2009: 20). Intrapreneurship tries to renovate and transform the main idea of entreprenual activities leading to the creation of a new enterprise within the organization (Sharma \& Chrisman, 1999: 12). Intrapreneurship can be seen as a system that enables the use of creative processes, introduces change through risk and proactive behavior that allows planning, designing and implementing the desired innovation activities (Echols \& Neck, 1998: 38).

There is a stagnation and lack of innovation in an organization in which entrepreneurs fulfill only their functional roles with minimum risk. Intrapreneurship focuses on reinvigorating and increasing the qualities of an organization to acquire the skills and abilities that can drive innovation activities (Hornsby et al., 2002). The intrapreneurial approach that used to take advantage of external opportunities was a widespread and result driven approach; it seems to be a necessity to develop opportunities based on innovations that lead to competitive advantages instead (Barca, 2009: 48).

Intrapreneurship allows large organizations to observe their activities, to continuously innovate and to innovate systematically (Naktiyok, 2004: 38). Being a pioneer in identifying and chasing new opportunities and participating in emerging markets is closely related to the activities of intrapreneurship (Ağca \& Kurt, 2007: 84). Intrapreneurship is a process that supports businesses in terms of developing new production methods and processes, renewing themselves and becoming the top in their market (Antoncic \& Hisrich, 2001: 495-497).

As can be seen in Figure 1, at the core of the phenomenon of intrapreneurship is the strategy of creating new service products and processes creatively by recognizing opportunities in the business environment and creating opportunities within resources of an organization. For this reason, bringing 
together opportunities, resources and organizational elements to create value is achieved by the intrapreneur who is the core of the process (Naktiyok \& Kök, 2006: 81). The strategic management cycle is completed by applying the generated plan and measuring the achieved goals and providing feedback to the next planning process (David, 2007: 56).

Figure 1.Intrapreneurship Process

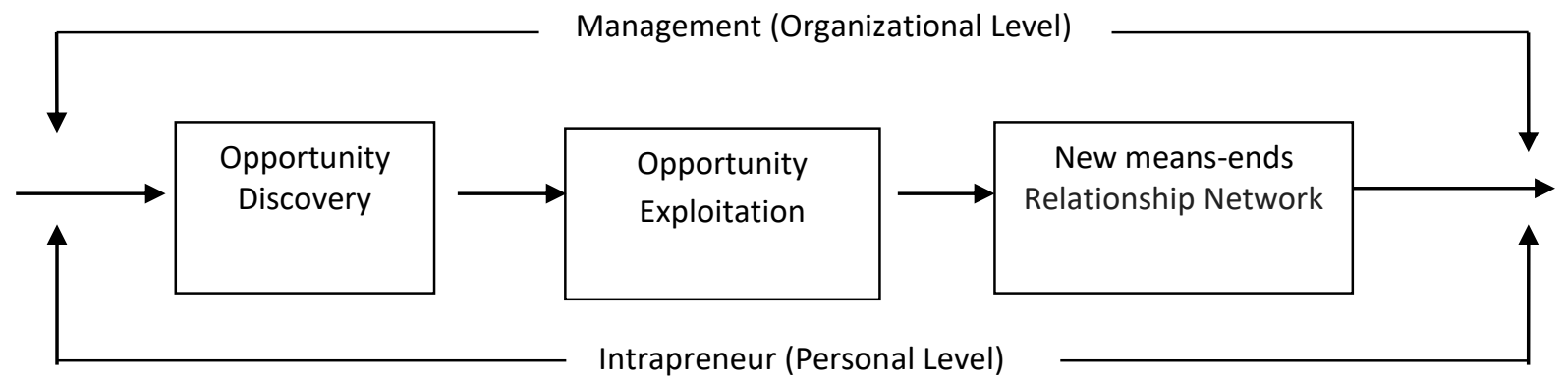

Source: Menzel, 2008: 24.

An important reason why intrapreneurship has attracted so much attention is that it offers opportunities that result in innovation that increases business performance (Zahra, 1991: 260). Intrapreneurship helps to strengthen and upgrade the basic skills of an existing business so that innovative skills can be achieved (Ağca \& Kurt, 2007: 90). Intrapreneurship is helping enterprises to cope with problems such as lost flexibility and ability to innovate due to their large scale (Thornberry, 2001: 533). Intrapreneurship is often focused on activities outside of the principal activities of the business in order to provide more value and consolidate the competitive position of the organization (Nielsen et al., 1985: 184).

Intrapreneurship needs intrapreneurial climate within an organization. According to the Hisrich et al. (2017: 44) characteristics of an entrepreneurial environment are: organization operates on frontiers of technology, new ideas encouraged, trial and error encouraged, failures allowed, no opportunity parameters, resources available and accessible, multidiscipline teamwork approach, long time horizon, volunteer program, appropriate reward system, sponsors and champions available, support of top management.

\subsubsection{Dimensions of Intrapreneurship}

Intrapreneurship has been observed in different models and dimensions by those who study the subject because of its peculiar characteristics. In this research, intrapreneurship consists of seven dimensions:

Table 1. Classification of Intrapreneurship

\begin{tabular}{|c|c|c|}
\hline $\begin{array}{l}\text { Innovativeness/ } \\
\text { Innovation }\end{array}$ & $\begin{array}{l}\text { Process of creating new products, services, } \\
\text { processes, technologies and methods }\end{array}$ & $\begin{array}{l}\text { Covin and Sleven(1991); Lumpkin and Dess } \\
\text { (1996); Knight (1997); Antoncicve Hisrich } \\
\text { (2001); Morris and Kuratko (2002) }\end{array}$ \\
\hline Risk Taking & $\begin{array}{l}\text { Making investment decisions and taking } \\
\text { strategic actions in an uncertain } \\
\text { environment to evaluate new } \\
\text { opportunities despite the possibility of } \\
\text { failure }\end{array}$ & $\begin{array}{l}\text { Miller and Friesen (1983); Covin and Slevin } \\
\text { (1991); Lumpkin and Dess (1996-2001); } \\
\text { Hornsby et al. (2002); Morris and Kuratko } \\
\text { (2002); Antoncic and Hisrich (2003) }\end{array}$ \\
\hline Proactiveness & $\begin{array}{l}\text { The tendency of the organization to } \\
\text { pioneer and initiate the first venture, } \\
\text { especially among the top management } \\
\text { staff }\end{array}$ & $\begin{array}{l}\text { Miller and Friesen (1983); Covin and Slevin } \\
\text { (1991); Lumpkin and Dess (1996-2001); } \\
\text { Knight (1997); Morris and Kuratko (2002); } \\
\text { Antoncic and Hisrich (2003) }\end{array}$ \\
\hline Autonomy & $\begin{array}{l}\text { The independence that an individual, } \\
\text { group or organization exhibits and } \\
\text { demonstrates an idea or vision }\end{array}$ & $\begin{array}{l}\text { Zajac et al. (1991); Lumpking and Dess } \\
\text { (1996); Culhane (2003) }\end{array}$ \\
\hline
\end{tabular}


The Integration of Strategic Management and Intrapreneurship: Strategic Intrapreneurship from Theory to Practice

Table 1. Classification of Intrapreneurship (Continued)

\begin{tabular}{|l|l|l|}
\hline $\begin{array}{l}\text { New Business } \\
\text { Venturing }\end{array}$ & $\begin{array}{l}\text { Creating new products, new jobs and new } \\
\text { autonomous units or semi-autonomous } \\
\text { firms in existing organizations }\end{array}$ & $\begin{array}{l}\text { Zahra (1991, 1993a, 1995); Stopford and } \\
\text { Baden-Fuller (1994); Zahra and Covin (1995); } \\
\text { Antoncic (2000); Antoncic and Hisrich (2001) }\end{array}$ \\
\hline $\begin{array}{l}\text { Self-renewal/ } \\
\text { Strategic } \\
\text { Renewal }\end{array}$ & $\begin{array}{l}\text { Reformulation of purpose and strategy, } \\
\text { redefinition of business concept, } \\
\text { reorganization and organizational change }\end{array}$ & $\begin{array}{l}\text { Guth and Ginsberg (1990); Zahra (1991; } \\
\text { 1993a); Stopford and Baden-Fuller (1994); } \\
\text { Antoncic (2000); Antoncic and Hisrich (2001, } \\
\text { 2003) }\end{array}$ \\
\hline $\begin{array}{l}\text { Competitive } \\
\text { Agressiveness }\end{array}$ & $\begin{array}{l}\text { Attacking (aggressively) or challenging } \\
\text { competitors and taking position directly } \\
\text { and intensely }\end{array}$ & $\begin{array}{l}\text { Covin and Covin(1990); Lumpkin and Dess } \\
\text { (1996); Antoncic (2000); Antoncic and Hisrich } \\
\text { (2003) }\end{array}$ \\
\hline
\end{tabular}

Source: Ağca \& Kurt, 2007: 92.

\subsection{Strategic Intrapreneurship}

Strategic intrapreneurship is the process of promoting and encouraging innovation and creating policies according to competitive advantages and core competencies in order to turn discoveries and opportunities into advantages independent of or dependent on resources under the dominance of employees in an operational context. It is the process of discovering innovations that are based on strategic intrapreneurship and future competitive advantages, and ensuring that business people strive to benefit from today's competitive advantages.

Strategic intrapreneurship has focused on the factors that promote intrapreneurial actions of all type of different groups in an organization (Hornsby et al., 2009: 237). According to Guth and Ginsburg (1990: 50) the aims of intrapreneurship are strategic renewal and the creation of new venture opportunities.

Strategic intrapreneur is the person who looks for opportunities and possibilities in this process, shows the ability to use them, and turns the opportunities into organizational realities despite the risks of career and job hunting. Strategic intrapreneurs engage in strategic intrapreneurship in line with their core competencies to provide a sustainable competitive advantage for the enterprise. Among the qualities of strategic intrapreneurs are features such as rational action by taking emotions under control, pursuing constant innovations, bringing together business people to produce a strategic plan, constantly feeding managers with new ideas and opportunities, and working to keep calm in times of crisis and conflict.

Strategic intrapreneurship needs organization which require champions and teams, resources, a concept, and management of the process (Hornsby et al., 2009: 238; Kuratko et al., 2015: 10). This kind of organization's staff has unique entrepreneurial behavior and different style of entrepreneurial thinking. Thus, Strategic intrapreneurship emerges as a result of strategic thinking and intrapreneurship. Traditional management practices lead to new enterprise failure and should be replaced by management action that supports the intraprenor. (Sykes \& Block, 1989: 161). It is important for the organizations need to acquire the staff who has the skill of strategic intent to reach strategic intraprenuership.

Organizations use policymakers and strategists to determine policies that enhance their competitiveness and competence which are based on their core competencies after identifying new opportunities and priorities. In order to gain a competitive advantage for the organization and to improve the performance of the organization, a series of harmonious strategies must be selected and implemented immediately by the managers (Hill \& Jones, 2012: 10). According to Liedtika (1998: 120), strategic thinking is about transforming everything about strategy into action which consists of five elements: a systematic unifying perspective, intention orientation, timely thinking, hypothetical versatility, and wise opportunities.

The organizational culture is an important requirement for strategic intraprenuership. Organizational culture is a key determinant of entrepreneurial activity within an organization (Cornwall \& Perlman, 1990: 66). The ability of an organization to develop and maintain strategic intraprenuership depends on its culture (Covin \& Slevin 1991: 16). In regards to the distinctive nature of strategic intraprenuership, an assessment can be made in the sense that the strategic decisions taken from the organizational culture.Therefore, 
organizational structure should be organized as flexible, responding quickly to developments on the periphery, open to teamwork, and has innovative resources (Efil, 1999: 294).

Steps that need to be taken in the creation of strategic intrapreneurship are development of vision, encourament of innovation, creating appropriate climate for intrapreneurs, and forming of teams (Kuratko \& Hodgetts, 1998: 64). Wolcott and Lippitz (2007: 76-79 have made important contribution in the field of intrapreneurship. They developed four models by observing famous companies that have benefited most from the intrapreneurship:

- The Opportunist Model: In this model, the approach of the intrapreneurship is not planned and directs the internal and external connections to the finding and the allocation of resources. Example, Zimmer.

- The Enabler Model: In this model, the enterprise allocates resources to inrapreneurship and senior management shows interest in prospective projects. Example, Google.

- The Advocate Model: In this model, the businessses provide a certain budget to support to their innovative staff in order to facilitate their intrapreneurship skills and create new jobs. Example, DuPont.

- The Producer Model: This model is aimed to reveal hidden intrapreneurs, develop cooperation between units, build potential for destructive management (continuously seeking better and targeting new) and creating new ways of working for managers to continue their careers outside their own units. Example, Cargill.

One of important factors in strategic intrapreneurship is the leader. The leader who has a strong influence on making the intrapreneurship an organizational concept, is also responsible on organizations employees. According to Antoniou and Ansoff (2004: 290), managers who are involved in direct strategy development in turbulent environments are more successful than strategists who prepare their company's future plans. In organizations that do not have strategic business intrapreneurs, managers try to apply their own ideas. The fact that managers or company owners have mistaken in perceiving environmental factors and their inability to use the resources of the company effectively and efficiently can jeopardize the company. According to Aktan (2008: 7), although strategic management is in fact related to top management, it is important to achieve a meaningful success, everyone in the position of expert, consultant, and manager taking part in the process must be correctly identified.

Strategic intrapreneurship is the most effective tool exploit of new discoveries and opportunities in the organization through creating new opportunities and finding new discoveries and opportunities in the direction of organizational goals and targets. Intrapreneurship is required as a method that enables more autonomy (autonomy), freedom and resource utilization among existing firms and enables them to innovate by using their creative energies (Ağca \& Kurt, 2007: 84). Sustainable competitive advantage goes beyond innovating, and the catalyst of innovation is inrapreneurship (Naktiyok \& Bayrak Kök, 2006: 94). Intrapreneurship can affect an economy, productivity gains, the emergence of best business practices, the creation of new industry areas, and the rise of international competition levels of businesses (Ağca \& Yörük, 2006: 162-163).

In strategic intrapreneurship, organizations seek to achieve strategic goals in order to discover innovations and take advantage of today's competitive advantages in the direction of its goals and objectives. In general, on the basis of the phenomenon of intrapreneurship, which reveals the sum of enterprise and innovation activities within an existing organization, it is the transformation of intrapreneurial thinking into the organization (Zahra et al., 2000: 947). In an environment characterized by vigorous competition, uncertain and complex market conditions, the only way to achieve sustainable competitive advantage is through innovation. Intrapreneurship requires managerial skills such as increasing the capacity of organizational innovation, managing knowledge, activating intellectual capital, creating innovative institutional culture, and organizational structures and systems to support them all (Barca, 2009: 48). Intrapreneurship is the evaluation of new potential opportunities in an uncertain environment, the 
harmonization of resources, and the promotion of innovation through the use and commercialization of such opportunities (McFadzean et al., 2005: 352).

Strategic intrapreneurship is an important tool to provide competitive advantage. It enables managers and employees to unlock intrapreneurial spirit to do something new, not to miss opportunities even in adverse conditions around them, and on this basis the business will become more effective in the competitive environment. Today, more organized and dynamic environments are being created for organizations and employees, together with regulations that allow for intrapreneurship within organizational structures (Feyzbakhsh et al., 2008: 172). Intrapreneurship basically depends on creating the environment that will allow the creation of innovations within organization itself (Morris \& Kuratko, 2000: 31). Employers with intrapreneurs are in an effort to develop new ways of doing business by targeting a vision to reach creative products and processes to achieve organizational goals and objectives (Lawson \& Samson, 2001: 389). Innovative organizations can develop a strong marketplace that can provide customer loyalty by adapting to market change (Naktiyok \& Bayrak Kök, 2006: 81).

Strategic intrapreneurship requires effective information management and effective communication within the organization. Knowledge and knowledge management is the essence of strategic management which is based on core competencies (Barca, 2009: 48). Intrapreneurship emphasizes organizational profitability, strategic renewal, innovation, knowledge acquisition and international success (Naktiyok \& Bayrak Kök, 2006: 81)

Effective support by the management within the organization, autonomy afforded to the employees, and providing proactive behavior will ensure strategic intrapreneurship's development and evolvement. Therefore, strategic management is a very useful resource in order to create an institutional game plan by harmonizing the independent actions and decisions of the managers and employees (Gül \& Çarıkçı, 2014: 24). Moreover, numerous research recommends strategic intrapreneurship as a method to enable staff to use more autonomy, freedom and resources and to innovate by using their creative energy (Gwendolyn, 2010: 144). Thus, the right to make decisions and taking responsibility in projects, intrapreneurship appears to be more evident (Onay \& Çavuşoğlu, 2010: 58). In an organization where innovation is important, in order an important concept such as strategic intrapreneur to exist, teamwork, decentralized decision-making processes, flexibility and open communication at organizational boundaries, promotion of risk taking, and toleration of mistakes are significant (Naktiyok, 2007: 215-216).

Incentive or reward system is also significant in the emergence of strategic entrepreneurs. By guiding employees through a properly designed reward system, employees in the organization are guided to exhibit intrapreneurship behaviors such as creative, proactive and affordable risk taking (Gürbüz et al., 2010: 129). Thanks to the use of the proper awards and incentives, intrapreneurs will be more prepared and willing to take risks associated with entrepreneurial activities (Kaya \& Arkan, 2005: 10).

\section{The Qualitative And Quantitative Research on Strategic Intrapreneurship}

The mixed research method (Baki \& Gökçek, 2012: 2; Creswell, 2015: 2), which uses qualitative and quantitative methods in the research, is used in this study. The combined use of quantitative and qualitative research methods could lead to many benefits (Fielding \& Fielding, 1986: 12). By using both methods together in terms of the reliability of the research, mixed research method eliminates the deficiencies of synthesis between the two methods and to achieve more reliable results (Butget Tunalı et al., 2016: 111). Rossman and Wilson has combined mixed research methods under three main titles: The two methods support and approve each other, allow for detailed and advanced analysis, and allow the emergence of new research topics as a result of contradictions that arise from the emergence of new insights. 
Figure 2. The Model Followed in the Research

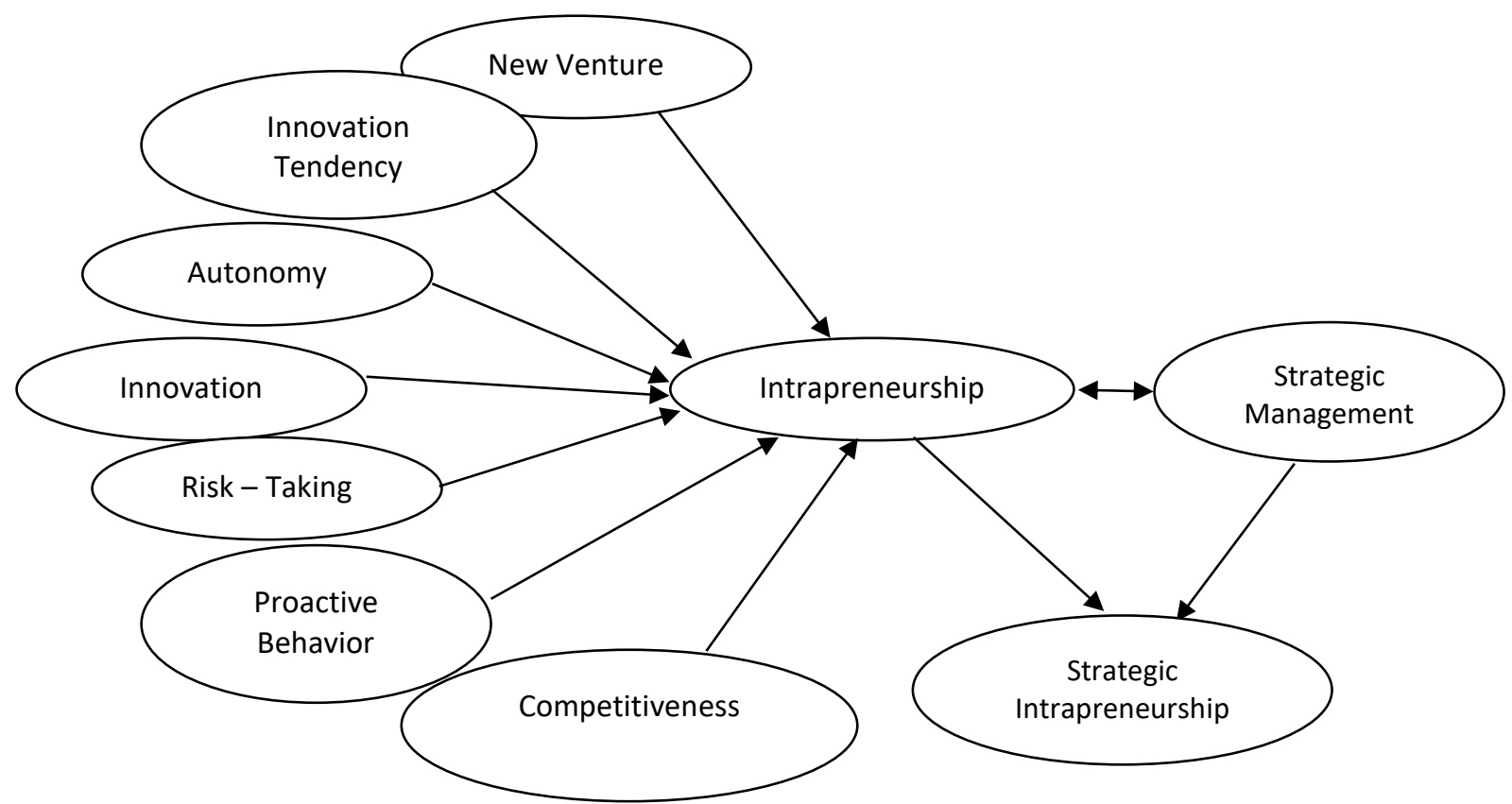

\subsection{Qualitative Research: SWOT Analysis}

Businesses make a variety of analysis to determine the benefits and disadvantages they might encounter in their immediate and distant surroundings. Strategic analysis consists of information gathering, appraisal and environmental analysis (Yılmaz, 2010: 111). Strategic analysis refers to the examination of the environmental elements and the evaluation of the elements within the organization.

The SWOT (Strengths, Weaknesses, Opportunites, and Threats) model is still being studied at the core of the literature on strategic management (Mintzberg et al., 1998: 28). The main purpose of the SWOT analysis is to determine the appropriate strategies to introduce an institution or organization into a specific model status or to identify actions to respond to the environment by comparing assets and resources (Hill \& Jones, 2012: 10). Thanks to this analysis, organizations can understand their market and competitors more clearly and determine their costs, objectives and strategies accordingly.

Strategic Entrepreneurs use this analysis to compare internal and external factors in order to get an idea about how businesses can be more successful. The Situational Analysis or the SWOT are analysis of the internal and external environment of organizations. In the analysis, the external environment is analyzed for internal environment, opportunities and threats for superiority and weaknesses. These elements are called strategic elements as they are the most important elements for the future of the business. The internal environment refers to the variables within the organization, but not in the short run, namely the advantages and weaknesses; whereas the external environment which are not controlled by the top management refers to variables outside the institution, namely opportunities and threats (Hunger \& Wheelen, 2007: 5-6).

In order to understand strategic intrapreneurship concept better, a textile factory of jeans fabric production in Malatya province has been selected for the research. This factory depends on new products and designs by white-collar workers. The firm produces raw materials to world famous jeans companies in the sector. Managerial (white collar) employees were involved in the research. In our research, before SWOT analysis is conducted; the topics have been determined in order to make both the SWOT analysis more systematic and to form a frame for the purposes, objectives, strategies and implementation of tools. Seven dimensionss of strategic intrapreneurship have been assigned according to their importance. 
- New Venture

- Innovation

- Innovation Tendency

- Proactive Behavior

- Risk Taking

- Autonomy

- Competitiveness

The intrapreneurship and its dimensions have been explained in detail to employees participating in our research. For the each title employees were asked to write their thoughts on the issues related to strengths, weaknesses, opportunities, and threats on the questionnaire. The data frequencies obtained through SWOT analysis have been determined and the maximum specified data have been regarded as the analysis result. The results are presented in Table 2 in detail.

Table 2. Strategic Intrapreneurship SWOT Analysis Results

\begin{tabular}{|c|c|c|c|c|}
\hline Dimensions & Strength & Weaknesses & Opportunities & Threats \\
\hline New Venture & $\begin{array}{l}\text { The firm's image } \\
\text { known all over the } \\
\text { world, the financial } \\
\text { status of the } \\
\text { company, instant } \\
\text { production } \\
\text { according to } \\
\text { customer requests }\end{array}$ & $\begin{array}{l}\text { Since some product } \\
\text { trials are expensive and } \\
\text { will take more time, } \\
\text { the new venture has } \\
\text { not been supported } \\
\text { adequately }\end{array}$ & $\begin{array}{l}\text { The firm's } \\
\text { involvement with } \\
\text { other well-known } \\
\text { jeans manufacturers } \\
\text { offers opportunities } \\
\text { for new ventures }\end{array}$ & $\begin{array}{l}\text { Developments in } \\
\text { technology, changes } \\
\text { in customer needs, a } \\
\text { constantly changing } \\
\text { product and } \\
\text { technology variety; } \\
\text { economic stagnation, } \\
\text { rising cotton prices, } \\
\text { new competitors } \\
\end{array}$ \\
\hline Innovation & $\begin{array}{l}\text { Use of new } \\
\text { technologies and } \\
\text { methods for new } \\
\text { production, } \\
\text { production of new- } \\
\text { comfortable and } \\
\text { popular jeans fabric }\end{array}$ & $\begin{array}{l}\text { Innovation is only on } \\
\text { jeans fabric, and there } \\
\text { are no innovation } \\
\text { activities in other } \\
\text { products or categories }\end{array}$ & $\begin{array}{l}\text { New clothing trends } \\
\text { and new product } \\
\text { allow new market } \\
\text { opportunities. } \\
\text { Popular culture is } \\
\text { useful for } \\
\text { innovations in jeans }\end{array}$ & $\begin{array}{l}\text { Risks of } \\
\text { dissatisfaction with } \\
\text { some new jeans } \\
\text { fabrics, the late } \\
\text { arrival of technology } \\
\text { and raw materials for } \\
\text { further production }\end{array}$ \\
\hline $\begin{array}{l}\text { Innovation } \\
\text { Tendency }\end{array}$ & $\begin{array}{l}\text { Immediate } \\
\text { organizational } \\
\text { change required for } \\
\text { new product }\end{array}$ & $\begin{array}{l}\text { In organizational } \\
\text { change, the probability } \\
\text { of some employees } \\
\text { dropping level of } \\
\text { productivity or leaving } \\
\text { work, }\end{array}$ & $\begin{array}{l}\text { Product-oriented } \\
\text { organizational } \\
\text { change or the } \\
\text { formation of new } \\
\text { organizational } \\
\text { structure, opening } \\
\text { up to new markets } \\
\text { and growing market } \\
\text { share, opportunity } \\
\text { to reach new } \\
\text { customers }\end{array}$ & $\begin{array}{l}\text { Through the } \\
\text { transformation in } \\
\text { organizational } \\
\text { structure, serious } \\
\text { threats such as } \\
\text { bankruptcy or loss of } \\
\text { market }\end{array}$ \\
\hline Autonomy & $\begin{array}{l}\text { Strong ties between } \\
\text { managers and other } \\
\text { employees, full } \\
\text { support for new } \\
\text { product trials }\end{array}$ & $\begin{array}{l}\text { Autonomy is limited } \\
\text { and not in all } \\
\text { production and } \\
\text { distribution processes; } \\
\text { promotion and salaries } \\
\text { of the company are not } \\
\text { at the desired level, }\end{array}$ & $\begin{array}{l}\text { Employees (white } \\
\text { collar workers) who } \\
\text { are fully } \\
\text { autonomous in the } \\
\text { workplace and on } \\
\text { the move are more } \\
\text { likely to have access } \\
\text { to new chances and } \\
\text { opportunities }\end{array}$ & $\begin{array}{l}\text { The possibility that } \\
\text { talented employees } \\
\text { who are fully } \\
\text { autonomous in the } \\
\text { business are } \\
\text { transferred by the } \\
\text { other competitor }\end{array}$ \\
\hline
\end{tabular}


Table 2. Strategic Intrapreneurship SWOT Analysis Results (Continued)

\begin{tabular}{|c|c|c|c|c|}
\hline Competitiveness & $\begin{array}{l}\text { The firm offers full } \\
\text { support for workers } \\
\text { in jeans fabric } \\
\text { production in their } \\
\text { efforts to access } \\
\text { new methods and } \\
\text { processes }\end{array}$ & $\begin{array}{l}\text { The firm does not } \\
\text { provide adequate } \\
\text { support for the use of } \\
\text { initiatives in other } \\
\text { matters, such as } \\
\text { financial advertising, } \\
\text { while giving full } \\
\text { initiative to employees } \\
\text { on new methods and } \\
\text { processes in the } \\
\text { production of jeans' } \\
\text { fabrics } \\
\end{array}$ & $\begin{array}{l}\text { With the new } \\
\text { products and } \\
\text { competitive agility, } \\
\text { the firm can enter } \\
\text { the market of other } \\
\text { competing } \\
\text { companies and } \\
\text { reach new } \\
\text { customers }\end{array}$ & $\begin{array}{l}\text { With competitive } \\
\text { aggressiveness, the } \\
\text { firm may face threats } \\
\text { to market } \\
\text { competitiveness and } \\
\text { forced to reduce } \\
\text { price in this regard } \\
\text { while entering } \\
\text { competitors' market }\end{array}$ \\
\hline Risk-Taking & $\begin{array}{l}\text { White-collar } \\
\text { workers are } \\
\text { supported by the } \\
\text { business on risk } \\
\text { taking. }\end{array}$ & $\begin{array}{l}\text { Risk taking is limited to } \\
\text { products only (jeans } \\
\text { fabric) and there is no } \\
\text { risk taking initiatives on } \\
\text { other issues such as } \\
\text { employee incentives. }\end{array}$ & $\begin{array}{l}\text { Employees with full } \\
\text { incentives can take } \\
\text { risks and access } \\
\text { opportunities such } \\
\text { as entering new } \\
\text { markets and } \\
\text { growing market } \\
\text { share in certain } \\
\text { production and } \\
\text { process } \\
\text { management }\end{array}$ & $\begin{array}{l}\text { The possibility of loss } \\
\text { of customers and } \\
\text { market with the risk } \\
\text { taken on the product } \\
\text { (jeans fabric); } \\
\text { economic stagnation, } \\
\text { increase in cotton } \\
\text { prices, emergence of } \\
\text { new competitors }\end{array}$ \\
\hline Proactive Behavior & $\begin{array}{l}\text { Employees in the } \\
\text { firm stated that } \\
\text { prior to the } \\
\text { competition, the } \\
\text { new product } \\
\text { development and } \\
\text { production line } \\
\text { consistently } \\
\text { supported proactive } \\
\text { behavior }\end{array}$ & $\begin{array}{l}\text { Proactive behavior is } \\
\text { generally limited to the } \\
\text { product (jeans fabric), } \\
\text { which is a disadvantage } \\
\text { of not being in other } \\
\text { areas }\end{array}$ & $\begin{array}{l}\text { The opportunity to } \\
\text { acquire new } \\
\text { customers and } \\
\text { capture new } \\
\text { markets with } \\
\text { products (jeans } \\
\text { fabric) that will } \\
\text { make customers feel } \\
\text { different and } \\
\text { precious }\end{array}$ & $\begin{array}{l}\text { Loss of material, } \\
\text { market and } \\
\text { customer in case of } \\
\text { introduction of a new } \\
\text { production before } \\
\text { the competitors }\end{array}$ \\
\hline
\end{tabular}

\subsection{Empirical Research on Strategic Intrapreneurship}

In order to understand strategic intrapreneurship concept better, a textile factory of jeans fabric production in Malatya province has been selected for empirical research. As mentioned before, this factory depends on new products and designs by white-collar workers. The firm produces raw materials to world famous jeans companies in the sector. Managerial (white collar) employees were involved in the research. The number of executives (white-collar) employee is 45 . Questionnaires were used in the study. The questionnaire of intrapreneurship which was developed by Serinkan and Arat (2013: 161-163) was derived from the various earlier studies. The sample size to be selected was calculated as 41 (The Survey System, 2014), with an error margin of $5 \%$ within $95 \%$ accuracy limits of the research universe.

However, a total of randomly chosen 45 employees were given questionnaires for the fact that some participants would not respond properly or give incorrect answer. 41 of the questionnaires answered and returned. The return rate of the questionnaires is $91.1 \%$. In this study, to achieve reliability 29 questions were asked in regards to intrapreneurship, and according to Likert scale 5, the reliability coefficient of Cronbach Alfa was calculated as 0.968 . As a result, it was concluded that the scale is highly reliable.

Strategic entrepreneurs in business are generally young. It is also noteworthy that $31 \%$ of total employees are a female employees in the firm and in terms of strategic intrapreneurship is significant. Also, 
all strategic entrepreneurs are college graduate and the importance of education in terms of strategic intrapreneurship is evident. In addition, the number of strategic intrapreneurs working in the company is around 7 years and over $70 \%$, and the number of new employees is relatively low.

Table 3. Demographic Findings

\begin{tabular}{|lcc|lcc|}
\hline Gender & $\mathbf{N}$ & $\mathbf{\%}$ & Education Status & $\mathbf{N}$ & $\mathbf{\%}$ \\
Male & 29 & 69 & Associate & 7 & 16.7 \\
Female & 13 & 31 & Undergraduate & 28 & 66.7 \\
& & & Graduate & 6 & 14.3 \\
& & PhD & 1 & 2.4 \\
\hline Age & $\mathbf{N}$ & $\%$ & Time worked in the Firm & $\mathbf{N}$ & $\%$ \\
$18-25$ ages & 3 & 7.1 & Less than a year & 3 & 7.1 \\
$26-35$ ages & 14 & 33.3 & 1-3 years & 7 & 16.7 \\
$36-45$ ages & 20 & 47.6 & 4-6 years & 3 & 7.1 \\
$46-55$ ages & 5 & 11.9 & 7-9 years & 3 & 7.1 \\
& & & 10 years and above & 26 & 62.0 \\
\hline
\end{tabular}

In the survey conducted, the arithmetical average of the intrapreneurship is $\overline{\mathrm{X}}: 3.90$, and it turns out that the ratio of intrapreneurship in its current form is at a high level. The new venture averages $\bar{X}: 3.97$, which reveals that employees are involved in new venture activities. With the innovation average of $\bar{X}: 3.77$, it appears that employees actively contribute to revealing new opportunities and taking chances in innovation activities that form the basis for intraprenuership. Innovation Tendency Average is at $\bar{x}: 3.95$. The result shows that employees are actively involved in organizational activities. Proactive Behavior averages $\overline{\mathrm{X}}$ : 4.03, which reveals that the problems that may arise in the future may arise before the action, such as in the cases of experimenting with new product or services before their competitors; experimenting with new markets or new methods, acting before their competitors. The risk taking average is $\bar{X}: 3.90$, and it turns out that the employees of the organization are willing to take risks in terms of their own careers, even the risk they will take, and the difficulty in operating the business to reach their business goals. Average autonomy dimension is $\bar{X}: 3.90$, shows that employees have independent mobility and decicison making in terms of an opportunity, an idea in an implementation phase. Competitiveness dimension averages $\bar{X}$ : with 3.68 results, it appears that employees are open to new methods and processes and at the same time have the desire to force their competitors in competition.

Tablo 4. Arithmetic Average and Standard Deviation of Intrapreneurship and its Dimensions

\begin{tabular}{|l|c|c|}
\hline & Average & Standard Deviation \\
\hline Intrapreneurship & 3.8974 & 0.61001 \\
\hline New Venture & 3.9694 & 0.69165 \\
\hline Innovation & 3.7698 & 0.68861 \\
\hline Innovation Tendency & 3.9464 & 0.70177 \\
\hline Proactive Behavior & 4.0298 & 0.73709 \\
\hline Risk-taking & 3.8968 & 0.69644 \\
\hline Autonomy & 3.9048 & 0.61225 \\
\hline Competitiveness & 3.6786 & 0.66094 \\
\hline
\end{tabular}




\subsection{Evaluation of Qualitative and Quantitative Findings in terms of Strategic Entrepreneurship}

The main purpose of the study is to describe a new field of strategic intrapreneurship. The study has been shaped around this purpose. The research has been tested with mixed research methods; empirical research and qualitative research techniques. A research model was developed in the direction of the literature review as indicated in figure 2 . According to the models developed by qualitative and quantitative research, the determination of risk taking, competitiveness, self-renewal, autonomy, proactive behavior, innovation, new enterprise dimensions have been observed. There seems to be a mutual relationship between the tendency of intrapreneurship and strategic management.

Information on the strengths and weaknesses of organizational intrapreneurs which can not be obtained through quantitative research is obtained through qualitative research. All the information obtained from the qualitative study is noteworthy and especially the emergence of weakness is important for strategic intrapreneurs. Therefore, the missing parts of the quantitative research can be complemented in more detail by qualitative research findings.

The strengths and weaknesses of the SWOT analysis are important and the firm should be careful in terms of strategic intrapreneurship because it informs the company about its internal environment and structure. Perceived environmental negativity or danger other than environmental dynamism, in other words, negative developments in the external environment, are among the factors considered to be very important for strategic intrapreneurship. The important thing is that in the direction of organizational goals, the internal factors and effectiveness can be used to minimize external threats, which basically defines strategic intrapreneurship.

In the quantitative study conducted in terms of strategic intrapreneurship, it is believed that the intrapreneurship and its dimensions show the behaviors of the intrapreneurship and dimensions of the workers are at a high level. The answers given by the SWOT analysis show that the results of the quantitative research reveals the results of the answers about the entrepreneurship dimensions. It appears that employees in the business are strategic entrepreneurs who are competent, forward-looking, constantly pursuing new products and new methods, chasing and evaluating opportunities with competitive personalities, in which they are strategic entrepreneurs in terms of their job and job descriptions.

Strategic intrapreneurs are employees who are self-confident, constantly in need of support in communication with top management and are constantly in need of support. Sometimes, they take strategic decisions and have the potential to show behavior that can create risks for themselves. Strategic intrapreneurs appear to have taken initiatives such as finding new products or developing products and driving the market before competitors, taking into account the future and objectives of businesses. Despite the fact that innovation tendency is one of the most troublesome areas in Turkish business, according to both quantitative and qualitative research results, strategic intrapreneurs are found not to be bothered about change and even shows their desire for change.

\section{Conclusion}

Strategic intrapreneurship is a meaningful and important term at the individual and organizational levels. Strategic intrapreneurship, which reveals the integration of entrepreneurship and strategy activities within an existing organization, leads individuals to believe that the individuals within an organization are important and necessary for the organization. Strategic intrapreneurship can be considered as guiding signs of success by contributing to the development of employees and hence organizational development by allowing institutions to survive. Strategic intrapreneurship organization has a positive influence on the productivity, effort and satisfaction of its employees.

The purpose of the paper is to explain a potential issue: strategic intrapreneurship, which is not subject to oversight and research with a different perspective on business and governmental management, and therefore, will provide important contributions to existing and newly opened businesses. 
The fact that organizations have strategic intrapreneurship is a very important issue for organizations' growth and for the continuation of organizations. The reason for this is that companies have to produce continuous strategies to overcome dilemmas such as change and continuity. Companies also need to promote intrapreneurship as it helps to identify with the organization. Another important aspect that should be emphasized in strategic intrapreneurship is the discovery of competent and effective individuals who distinguish themselves from their competitors.

In an organization in which the desired strategic intrapreneurial behavior can be achieved, it is necessary to avoid practices that impede the development of strategic intrapreneurial thinking. When we look at the average of the organizational factors that are believed to affect the issue of strategic intrapreneurship, it seems that organizational and managerial support is the factor that can most support strategic intrapreneurship. Strategic plans for the future by organizational managers are important because they consider the effectiveness, and efficiency of strategic intrapreneurship. While the strategic plans are being prepared, the participation of all employees and even the other stakeholders in the organization and their participation will increase the effectiveness of strategic entrepreneurship.

Creating strategic intrapreneurship culture is very important for strategic entrepreneurship. Strategic entrepreneurship culture is a medium where the participation of all employees is provided by the organization and it is here that strategy preparation, implementation, evaluation and feedback are continuously provided. Strategic entrepreneurship culture provides an organizational framework for developing organizational skills and feeling the environmental changes. The role of managers in establishing a work environment where employees will be productive, satisfied and extra effort is important: strategic culture of intrapreneurship, and the emergence of intrapreneurial ideas for employees needs to promoted within the organization.

\section{End Notes}

1. An earlier version of the paper was presented at the ICESSS'19 II. International Conference on Empirical Economics and Social Sciences (June 20-22, 2018, Bandırma, Balıkesir).

\section{References}

Ağca, V., \& Kurt, M. (2007). İ̧̧ girişimcilik ve temel belirleyicileri: Kavramsal bir çerçeve. Erciyes Üniversitesi iktisadi ve idari Bilimler Fakülte Dergisi, 29, 83-112.

Aktan, C. (1999). 2000'li yıllarda yeni yönetim teknikleri 2- Stratejik yönetim. İstanbul: TÜGiAD Yayını.

Aktan, C. (2008). Stratejik yönetim ve stratejik planlama. Çimento işsveren Dergisi, 22(4), 4 - 21.

Alparslan, A. M., \& Çarıkçı, İ. H. (2014). İşletmede strateji oluşturma yaklaşımlarını değerlendirmeye yönelik bir vaka çalışması. İstanbul Üniversitesi İşletme iktisadı Enstitüsü Dergisi, (76), 18-44.

Antoncic, B. (2000). Intrapreneurship: Construct refinement and an integrative model development. Case Western Reserve University, School of Graduate Studies, Thesis for the Degree of Doctor of Philosopy.

Antoncic, B., \& Hisrich, R. D. (2001). Intrapreneurship: Construct refinement and cross-cultural validation. Journal of Business Venturing, 16(5), 495-527.

Antoncic, B., \& Hisrich, R. D. (2003). Clarifying the intrapreneurship concept. Journal of Small Business and Enterprise Development, 10(1), 7-24.

Antoniou, P. H., \& Ansoff, H. I. (2004). Strategic management of technology. Technology Analysis \& Strategic Management, 16(2), 275 - 291.

Arıkan, S. (2004). Girişimcilik temel kavramlar ve bazı güncel konular. Ankara: Siyasal Kitabevi.

Baki, A., \& Gökçek, T. (2012). Karma yöntem araştırmalarına genel bir bakış. Elektronik Sosyal Bilimler Dergisi, 11(42), 121.

Barca, M. (2009). Stratejik yönetim düşüncesinin gelişimi. ASO Medya, Sayı Nisan/Mayıs/Haziran, 34 - 52. http://www.aso.org.tr/b2b/asobilgi/sayilar/dosyanisanmayishaziran20091.pdf (Erişim Tarihi: 29 Temmuz 2018). 
Barutçugil, ì. (2004). Stratejik insan kaynakları yönetimi. İstanbul: Kariyer Yayıncılık.

Başar, M., \& Tosunoğlu, T. (2006). Değer yaratımında iç girişimciliğin değişen boyutu: Bilgi girişimcilerinin rolü. Girişimcilik ve Kalkınma Dergisi, 1(1), 123-136.

Bryson, J. M. (1988). Strategic planning for public and nonprofit organizastions. California: Jossey-Bass Publishers.

Butget Tunalı S., Gözü, Ö., \& Özen, G. (2016). Nitel ve nicel araştırma yöntemlerinin bir arada kullanılması 'karma araştırma yöntemi'. Anadolu Üniversitesi Iletişim Bilimleri Fakültesi Uluslararası Hakemli Dergisi, 24(2), $106-112$.

Carrier, C. (1996). Intrapreneurship in small businesses: An exploratory study. Entreprneurship Theory and Practice, 21(1), 5-20.

Cornwall, J. R., \& Perlman, B. (1990). Organizational entrepreneurship. Homewood: Irwin.

Covin, J. G., \& Covin, T. J. (1990). Competitive agressiveness, environmental context, and small firm performance. Entrepreneurship Theory and Practice, 14(4), 35-50.

Covin, J. G., \& Slevin, D. P. (1989). Strategic management of small firm in hostile and benign environments. Strategic Management Journal, 10(1), 75-87.

Covin, J. G., \& Slevin, D. P. (1991). A conceptual model of entrepreneurship as firm behavior. Entrepreneurship Theory and Practice, 16(1), 7-25.

Creswell, J. W. (2015). A concise introduction to mixed methods research. Thousand Oaks, CA: SAGE Publications.

Culhane, J. H. (2003). The entrepreneurial orientation-performance linkage in high technology firms: An international comparative study. Graduate School of Te University of Massachusetts Amherst, Thesis for the Degree of Doctor of Philosopy.

David, F. R. (2007). Strategic management consept and cases. New Jersey: Prentice Hall.

Dinçer, Ö. (2007). Stratejik yönetim ve işletme politikası (8. Baskı). İstanbul: Alfa Yayınevi.

Echols, A. E., \& Neck, C.P. (1998). The impact of behaviors and structure on corporate entrepreneurial success. Journal of Managerial Psychology, 13(1/2), 38-46.

Efil, ì. (1999). Işletmelerde yönetim ve organizasyon. İstanbul: Alfa Yayınları.

Eren, E. (1990). İşletmelerde stratejik planlama ve yönetim. İstanbul: İşletme Fakültesi Yayınları.

Eren, E. (2010). Stratejik yönetim ve işletme politikası (8. Baskı). İstanbul: Beta Basım Yayım Dağıtım.

Ertuna, Ö. (2008). Stratejik yönetim (4. Baskı). İstanbul: Okan Üniversitesi Yayınları.

Feyzbakhsh, A., Sadeghi, R., \& Shoraka, S. (2008). A case study of intrapreneurship obstacles: The RAJA passenger train company. Journal of Small Business and Entrepreneurship, 21(2), 171-180.

Fielding, N., \& Fielding, J. (1986). Linking data: The articulation of qualitative and quantitative methods in social research. London and Beverly Hills: Sage.

Greene, J. C., Caracelli V. J., \& Graham, W. F. (1989). Toward a conceptual framework for mixed method evaluation designs. Educational Evaluation and Policy Analysis, 11(3), 255-274.

Gürbüz, S., Bekmezci, M., \& Mert, í. S. (2010). Örgütsel faktörlerin iç girişimciliğe etkisi: ilş tatmini aracı değişken mi? Organizasyon ve Yönetim Bilimleri Dergisi, 2(2), 127-135.

Guth, W. D., \& Ginsberg, A. (1990). Guest editors' introduction: Corporate entrepreneurship. Strategic Management Journal, 11(5), 5-15.

Guth, W. D., \& Ginsberg, A. (1990). Guest editors "introduction: Corporate entrepreneurship". Strategic Management Review, 2(special issue), 5-50.

Gwendolyn, R. (2010). Intrapreneurship in a fast growing economy: A study of the Emirates of Dubai. The Business Review, Cambridge, 15(2), 144-150.

Hill, C. W., \& Jones, G. R. (2012). Essentials of strategic management. South-Western, Cengage Learning.

Hisrich, R.D., Peters, M. P., \& Sheperd, D. A. (2017). Entrepreneurship (10th ed.). New York, NY: McGraw-Hill Irwin.

Hornsby, J. S., Kuratko, D. F., \& Zahra, S. A. (2002). Middle managers perception of the internal environment for corporate entrepreneurship: Assessing a measurement scale. Journal of Business Venturing, 17 (3), 253-273.

Hornsby, J. S., Kuratko, D. F., Shepherd, D. A., \& Bott, J. P. (2009). Managers' corporate entrepreneurial actions: Examining perception and position. Journal of Business Venturing, 24(3), 236-247.

Hunger, D., \& Wheelen, T. L. (2007). Essentials of strategic management. New Jersey: Upper Saddle River. 
The Integration of Strategic Management and Intrapreneurship: Strategic Intrapreneurship from Theory to Practice

Kaya, N., \& Arkan, A. F. (2005). Örgütsel faktörlerin şirket girişimciliğinin potansiyel sonuçlarına etkileri: Bilgi teknolojileri ve iletişim sektöründe bir araştırma. Istanbul Üniversitesi Iş̧letme Fakültesi Iş̧letme Iktisadı Enstitüsü Yönetim Dergisi, 16(52), 7-16.

Kirby, D. A. (2003). Entrepreneurship. New York: McGraw-Hill Publication.

Knight, G. (1997). Cross-cultural reliability and validiryof a scale to measure firm entrepreneurial orientation. Journal of Business Venturing, 12(3), 213-225.

Koçel, T. (1998). Girişimcilik ama hangisi? Executive Excellence, 10, 17-18.

Koçel, T. (2007). İşletme yöneticiliği. İstanbul: Beta Basım Yayım.

Koteen, J. (1997). Strategic management in public and nonprofit organizations: Managing public concerns in an era of limits. Westport, CT: Praeger Publishers

Kuratko, D. F., \& Hodgetts, R. M. (1998). Entrepreneurship: A contemporary approach (Fourth Edition). Orlando, Fl: The Dreyden Press.

Kuratko, D. F., \& Hodgetts, R. M. 2001. Entrepreneurship: A contemporary approach. Mason, Ohio: South-Western Thonson Learning.

Kuratko, D. F., \& Morris, M. (2018). Corporate entrepreneurship: A critical challenge for educators and researchers. Entrepreneurship Education and Pedagogy, 1(1), 42-60

Kuratko, D. F., \& Welsch, H. P. (1994). Entrepreneurial strategy text and cases. Fort Worth, TX: The Dryden Press.

Kuratko, D. F., Hornsby J. S., \& Sabatine, F. J. (1999). The breakthrough experience: A guide to corporate entrepreneurship. Midwest Entrepreneurial Education Center, College of Business Ball State University.

Kuratko, D. F., Hornsby, J. S., Naffziger, D. W., \& Montagno, R. V. (1993). Implement entrepreneurial thinking in established organizations. SAM Advanced Management Journal, 58(1), $28-39$.

Kuratko, D. F., Montagno, R. V., \& Hornsby, J. S. (1990). Developing an intrapreneurial assessment instrument for effective corporate entrepreneurial environment. Strategic Management Journal, 11(5), 49-58.

Kuratko, D. F., Morris, M. H., \& Schindehutte, M. (2015). Understanding the dynamics of entrepreneurship through framework approaches. Small Business Economics, 45, 1-13.

Lawson, B., \& Samson, D. (2001). Developing innovation capability in organisations: A dynamic capabilities approach. International Journal of Innovation Management, 5(3), 377-400.

Liedtika, J. M. (1998). Strategic thinking: Can it be taught? Elsevier Science, 31(1), 120 - 129.

Luchsinger, V., \& Bagby, D. R. (1987). Entrepreneurship and intrapreneurship: Behaviours, comparisons, and contrasts. Sam Advanced Management Journal, 52(3), 10-13.

Lumpkin, G. T., \& Dess, G. G. (1996). Clarifying the entrepreneurial orientation cunstruct and linking it to performance. Academy of Management Review, 21(1), 135-172.

Lumpkin, G. T., \& Dess, G. G. (2001). Linking two dimensions of entrepreneurial orientation to firm performance: The moderating role of environment and industry life cycle. Journal of Business Venturing, 16(5), 429-451.

McFadzean, E., O'Loughlin A., \& Shaw, E. (2005). Corporate Entrepreneurship and innovation part 1: The missing link. European Journal of Innovation Management, 8(3), 350-372.

Menzel, H. (2008). Intrapreneurship-conducive culture in industrial R\&D. Eindhoven: Eindhoven University Press.

Miller, D., \& Friesen, P. H. (1983). Strategy-making and environment: The third link. Strategic Management Journal, 4(3), 221-235.

Mintzberg, H., Ahlstrand, B., \& Lampel, J. (1998). Strategy safari. New York: The Free Press.

Morris, M., \& Kuratko, D. F. (2002).Corporate entrepreneurship: Entrepreneurial development within organizations. Orlando-Florida: Harcourt College Publishers.

Naktiyok, A. (2004). İç girişimcilik (1. Baskı). İstanbul: Beta.

Naktiyok, A. (2007). Yenilik yönelimi ve örgütsel faktörler. Atatürk Üniversitesi iktisadi ve Idari Bilimler Dergisi, 21(2), 211-230.

Naktiyok, A., \& Bayrak Kök, S. (2006). Çevresel faktörlerin iç girişimcilik üzerine etkileri. Afyon Kocatepe Üniversitesi i.i.B.F. Dergisi, 8(2), 77-96.

Nielsen, R. P., Peters, M. P., \& Hisrich, R. D. (1985). Intrapreneurship strategy for internal markets - Corporate, nonprofit and government institution cases. Strategic Management Journal, 6(2), 181-189. 
Onay, M., \& Çavuşoğlu, S. (2010). İşletmelerde girişimcilik özelliğini etkileyen faktörler: İç girişimcilik. Yönetim ve Ekonomi, 17(1), 47-67.

Parker, S. (2009). Intrapreneurship or entrepreneurship? Journal of Business Venturing, 26, 19-34.

Parnell, J. A. (2014). Strategic management; theory and practice. California: SAGE Publications.

Pinchot, G. (1985). Intrapreneuring: Why you don't have to leave the corporation to become an entrepreneur. New York: Harper and Row.

Rossman, G. B., \& Wilson, B. L. (1994). Numbers and words revisited: Being 'shamelessly eclectic. Quality and Quantity, 28(3), 315-327.

Schumpeter, J. A. (1934). The theory of economic development. Cambridge, MA: Harvard University Press.

Serinkan, C., \& Arat, G. (2013). İşletmelerde örgütsel değişim ve iç girişimcilik. İstanbul: Beta Basım.

Sharma, P., \& Chrisman, J. J. (1999). Toward a reconciliation of the definitional issues in the filed of corporate entrepreneurship. Entrepreneurship Theory and Practice, 23(3), 11-27.

Söyler, í. (2007). Kamu sektöründe stratejik yönetim uygulanabilir mi? Maliye Dergisi, 103-115.

Sykes, H.B., \& Block, Z. (1989). Corporate venturing obstacles. Journal of Business Venturing, 4, $159-167$.

The Survey System, (2012). Sample size calculator. http://www.surveysystem.com/sscalc.htm (Erişim Tarihi: 26 Haziran 2018).

Thompson, A. A., \& Strickland, A. Y. (1987). Strategic management concept and cases (Fourth Edition). Plano Texas: Business Publication.

Thornberry, N. (2001). Corporate entrepreneurship: Antidote or oxymoron? European Management Journal, 19(5), 526533.

Top, S. (2006). Girişimcilik-keşif süreci. İstanbul: Beta Yayınları.

Torlak, Ö., \& Uzkurt, C. (1999). Belediyelerde hizmet anlayışı ve stratejik yönetime geçiş. Kamu Yönetiminde Kalite 2. Ulusal Kongresi, TODAiE Yayın No: 296,

Ülgen, H., \& Mirze, S. K. (2004). Iş̧letmelerde stratejik yönetim. İstanbul: Literatür Yayınları.

Wolcott, R. C., \& Lippitz, M. J. (2007). The four models of corporate entrepreneurship. MIT Sloan Management Review, $49,75-82$

Zahra, S. A. (1991). Predictors and financial outcomes of corporate entrepreneurship: An exploratory study. Journal of Business Venturing, 6(4), 259-285.

Zahra, S. A. (1993). Environment, corporate entrepreneurship, and financial performance: A taxonomic approach. Journal of Business Venturing, 8(4), 319-340.

Zahra, S. A. (1995). Corporate entrepreneurship and financial performance: The case of management leveraged buyouts. Journal of Business Venturing, 10(3), 225-247.

Zahra, S. A., \& Covin, J. G. (1995). Contextual influences on the corporate entrepreneurship performance relationship: A longitudinal analysis. Journal of Business Venturing, 10(1), 43-58.

Zahra, S. A., Neubaum, D. O., \& Morten, H. (2000). Entrepreneurship in medium-size companies: Exploring the effects of ownership and governance systems. Journal of Management, 26(5), 947-976. 
This Page Intentionally Left Blank 